\title{
O futuro do SUS
}

Não é aconselhável fazer futurologia em política de saúde. Mas, diante do desafio do tema é pertinente refletir sobre a sustentabilidade econômica, política e institucional do SUS, partindo do pressuposto de que não há política irreversível. Ainda que assentado na Constituição e nas leis, o SUS não está livre de retrocessos. Basta olhar o que está acontecendo em Portugal, Grécia, Espanha e Itália para compreender a vulnerabilidade dos sistemas de saúde diante de crise econômica ou política. No Brasil, festejado como a sexta economia do mundo, dois dos Poderes da República inviabilizaram, recentemente, recursos adicionais para o SUS.

Na bonança houve recursos para o Programa de Aceleração do Crescimento e para as obras da Copa do Mundo. Mas diante da tempestade na saúde da economia, o governo prefere comprometer o direito universal à saúde. O Estado brasileiro contenta-se em cobrir apenas $41 \%$ do gasto em saúde, quando a maior parte dos países que optaram por sistemas universais responsabilizam-se por mais de $80 \%$ desta despesa. Não há sinais de políticas que incrementem recursos federais nos próximos anos, contemplando investimentos para a ampliação da infraestrutura e o custeio da rede de serviços. A sustentabilidade econômica encontra-se ameaçada e uma das justificativas apresentadas para a rejeição do projeto que obrigava a destinação de $10 \%$ do orçamento federal para a saúde foi a crise internacional.

No caso da sustentabilidade política caberia analisar quais forças políticas e sociais defendem efetivamente o SUS, de acordo com os princípios e diretrizes dispostos na legislação, e quais se aproveitam das suas fragilidades para ampliar a mercantilização e a privatização, diante das ambiguidades e omissões da regulação estatal. A população e parte significativa dos trabalhadores de saúde vivem o pior dos mundos: um setor público subfinanciado e um setor privado sub-regulado. No entanto não há uma mobilização social suficiente que pressione partidos, parlamentares e dirigentes a reverterem esse quadro.

A Reforma Sanitária concebeu a seguridade social (cidadania universal) e uma engenharia decisória calcada em conselhos e conferências, paritários e deliberativos. Na saúde ampliou-se a cobertura e o acesso aos serviços nos diversos níveis, na previdência resta um seguro social (cidadania regulada) cada vez mais restritivo após sucessivas reformas, e na assistência social predomina a transferência condicional de renda para pobres e miseráveis (cidadania invertida). E diante do refluxo ou cooptação de movimentos sociais os canais de participação cidadã têm sido colonizados por interesses privados, partidários e corporativos, enquanto os milhares de cargos de confiança são utilizados nas transações políticas. Portanto, a sustentabilidade institucional do SUS sofre abalos a cada mudança de governo ou de gestor quando quadros técnicos e gerenciais são substituídos, independentemente da qualificação e do mérito.

O futuro do SUS depende do que se faz hoje. O subfinanciamento público e os estímulos aos planos privados de saúde, inclusive ampliando o seu mercado mediante a inclusão de funcionários públicos e da chamada "classe C", apontam para a reprodução de um SUS pobre para os pobres e complementar para o setor privado, sobretudo nos procedimentos de alto custo. As políticas racionalizadoras ora implementadas, embora relevantes, não são suficientes para renovar as esperanças por um sistema de saúde digno, democrático e de qualidade para todos os brasileiros. 


\section{The future of the Brazilian Unified National Health System}

Futurology is normally contra-indicated in health policy. However, the economic, political, and institutional sustainability of the Brazilian Unified National Health System (SUS) is so challenging that reflection on the issue is important, on the assumption that no policy is irreversible. Although grounded in the 1988 Constitution and related legislation, the SUS is not immune to backsliding. Recent events in Portugal, Greece, Spain and Italy clearly illustrate the vulnerability of health systems to economic and political crises. In Brazil (now feted as the world's 6th leading economy), two of the three Branches of government have recently blocked the earmarking of additional funds for the SUS.

In times of plenty, there were sufficient resources for the Growth Acceleration Program (PAC) and construction projects for the 2014 World Football Cup, to be hosted by Brazil. But with a storm raging in the health of the economy, the government prefers to sacrifice the universal right to health. The public sector in Brazil covers only $41 \%$ of all national health expenditures, while in most countries that have opted for universal systems, the governments pay more than $80 \%$ of this expense. There are no signs of policies to increase Federal funds in the coming years, such as investments to expand the health services' infrastructure or cover costs. The SUS' economic sustainability is in jeopardy, and the international crisis was one of the justifications for rejecting the bill to earmark $10 \%$ of the Federal budget for health.

The case of political sustainability calls for an analysis of the political and social forces that truly defend the SUS according to the principles and guidelines laid out in the legislation, as opposed to those that take advantage of the system's weaknesses to expand its commodification and privatization by exploiting the ambiguities and loopholes in state regulation. The Brazilian population and a significant portion of health workers thus live in the worst of all worlds: an underfinanced public sector and an under-regulated private sector. Meanwhile, no social mobilization is now in sight to pressure the political parties, Congress, and administrators into reversing the situation.

The Brazilian Health Reform conceived social security (universal citizenship) and decision-making engineering based on health councils and conferences with balanced, deliberative representation. Health coverage and access to health services were expanded at various levels, what is left of social security is a kind of social insurance (regulated citizenship, increasingly restrictive after successive reforms), and social assistance is based predominantly on conditional income transfer to the poor and destitute (inverted citizenship). And given the paralysis or cooptation of Brazil's social movements, the channels for citizens' participation have been colonized by private, partisan, and corporatist interests, while thousands of political posts are negotiated in political transactions. The SUS' institutional sustainability thus suffers shocks with each change of administration or administrator, when technical and management personnel are replaced, regardless of their qualifications or merits.

The SUS' future hinges on what is done today. Public under-financing and incentives for private health plans (including the expansion of the latter's market through the inclusion of civil servants and the so-called "class C", or new middle class) all point to the reproduction of a "poor SUS for the poor" that is meanwhile complementary for the private sector, especially for high-cost procedures. The rationalizing policies now being implemented, although important, are not sufficient to renew hopes for a decent, democratic, high-quality health system for all Brazilians. 